\title{
Unmask the Truth: A Study of Deepanjana Pal's Hush a Bye Baby
}

\author{
A Manimegala ${ }^{1}$ and R. Rajavelu ${ }^{2}$ \\ ${ }^{1}$ Kanchi Mamunivar Government Institute for Post Graduate \\ Studies and Research Lawspet, Puducherry, India \\ ${ }^{2}$ Department of English, Kanchi Mamunivar Government Institute for Post \\ Graduate Studies and Research Lawspet, Puducherry, India
}

\begin{abstract}
This existing research paper highlights the heinous crime threatening the Indian society, is seen through the famous Indian writer Deepanjana Pal's debut novel Hush A Bye Baby. This paper pays close attention on female foeticide and gives voice to the voiceless female infanticide. The centre character Dr. Nandita Rai, a gynaecologist cum female icon believes that women and girls will not be safe in this patriarchal world in future. According to her, killing, the girl foetus in the womb of the mother is the only solution to safeguard the women and the girl child from the future brutalities. Sex-selective abortion is treated as the most serious issue from the ancient period till the contemporary time for various reasons. The lack of education and wealth made people think of female foeticide in olden days. Now educated and wealthy people also things the same for some other reason. It's only the change in reason but the mindset stays stable.
\end{abstract}

KEY WORDS: FEMALE FOETICIDE, SOCIAL ISSUES, PATRIARCHAL SOCIETY, TECHNOLOGY, MATERIALISTIC WORLD, POWER HIERARCHY, ETC.

\section{INTRODUCTION}

\section{Definition of crime: Crime is an act forbidden by law and revolting to the moral sentiments to the society - says Sir James Stephen.}

Literary Review: Crime fiction an emerging genre creates its own path in Indian literature in the contemporary time usually women and girl children are targeted by the predators. As literature reflects human life, crime writing reflects the social issues and problem of the society. Many writers write crime fiction for reading pleasure but some writers exposed social problem through crime fiction. As everything is based on the technology, modern world crime also became different in its way and method. Earlier Indian writers gave more importance to family relationship, romance, sentiments that leads them to the

Biosc Biotech Res Comm P-ISSN: 0974-6455 E-ISSN: 2321-4007

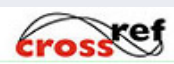

Identifiers and Pagination

Year: 2021 Vol: 14 No (8) Special Issue

Pages: 102-104

This is an open access article under Creative

Commons License Attribn 4.0 Intl (CC-BY). DOI: $h t t p: / / d x$.doi.org/10.21786/bbrc/14.8.25 social problems occurring in the society. Every crime has its own motive and past life.

Introduction: This is one of the themes, in the crime fiction Hush a Bye Baby. Many women journalist started writing crime fiction from their real life experience to give awareness. Deepanjana Pal is a journalist and critic with over a decade's experience in writing about culture, gender and society. Our world is completed surrounded by different types of crime. And this novel which is completely different from the usual crime writing. Deepanjana Pal is not only a well know writer of the contemporary society but also a famous journalist. The experience gained in the field and the mind to write it in a form made her to write this novel Hush a Bye Baby. This novel explores the unnoticeable issues that happening in the top most city like Mumbai. Even in this, 21st century were women are given more priority are facing too many problems like power corruption, female foeticide, male dominance, etc. The writer Deepanjana Pal spotlights the terrifying problem of female foeticide.

Stereotype of Woman: Dr. Nandita Rai is a renowned gynaecologist who gives voice about the welfare of women; she is also seen as a female icon by the society.
Article Information

Received: $13^{\text {th }}$ Apr 2021 ccepted after revision: $11^{\text {th }}$ June 2021 
From the history it is well-known that female infants are killed by giving toxic milk, because in the olden days people think there is no benefit in bringing up a girl child in the society, for they think male as an 'asset' who supports the family, whereas a daughter has to get married to another family.. However, the same thing happens in this novel but for a different reason. Male chauvinism could not accept women to be a superior. Men use the weakness of women and girls to abuse both physically and mentally, not to satisfy their pleasure, but to dominate and suppress them. From history and cultural background, it is done due to social and economic reasons. Even the dowry prohibition Act of 1961 is passed that does not make any change in the tradition of giving dowry. "Sex selective abortion lowers the cost of discrimination and many people think that it is better to pay a 500 rupees now (abortion) instead of 50,000 rupees in the future dowry." Until 1980's female foeticide happened once they were born, but the horrifying truth is that because of the development of technology they are killed inside the womb of the mother.

Dr. Rai's happy life with her husband Naveen Rai and the only son Nishant comes to an end by a terrible incident that shakes the whole life of Dr. Rai and affects her psychologically. India is a country where women are treated equal to god and worshipped at some point. At the same time many women are affected by the same people. Usually the ambitious greed for money or power provokes them to the path of crime. However, in the case of Dr. Rai, she does crime of sex selection abortion knowing the human values for the sake of the female child's future life. Her prejudice on the future society or world that provokes her commits the crime of female foeticide. Moreover, she justifies it from her point of view, For instance: "A girl is born stronger, better developed, more likely to fight and survive."(Web) Girls and women are made weaker as they grow older, only by the society by thinking, Girls are 'liabilities' and boys are 'assets' that wave's path for Sex based discrimination.

Female Foeticide: Dr. Rai says, "A child has the right to live ( HBB 172)." She said abortion was the most humane option "under the circumstances." Every mother tries her best to raise her child to be good but sometime she fails in it. Dr. Rai thinks herself as a mother of the entire fetus in the womb of her patient, and decides to save them through killing them. She was very much traumatized by this incident but does not have any other option to protect them from this evil society. Dr. Nandita Rai uses anencephaly as a tool to kill the child that too with the knowledge of the parent. Because everyone desires for a healthy child. So they are convinced of doing an abortion to the advice of their Doctor. "If a person kills a life it should be treated as a murder. So, killer of female foetus should be treated as a murder in the same way." The rationale behind the female foeticide in Indian society has various reasons like economic, social status, ritual, horoscope, cultural politics (dowry), honour killing etc. I need to tell you, because this shame and this guilt are overwhelming. My son, the boy that I gave birth to after hours of painful labour, the child for whom I have sacrificed and tolerated so much, that boy proven to be the worst kind of human being. My son raped a girl, but a friend of his. (HBB 206).

Psyche of Dr. Nandita Rai: When a complaint was filed against my son Nishant, my husband Naveen Rai construction magnate, a close friend of commissioner made the complaint disappear, within a few hours. "I just want to share this because the pretence that, there is nothing wrong in killing my very soul." She was taking revenge for all the girls who had been killed in the womb. "This project may sound brutal and in a sense, it is. But the attempt was to nip a problem in the bad so that other brutalities take place or at least happen less.”(HBB 232) Her son's crime hushed up had turned her into Doctor Death. She posts an article on the day she kills a child. Nandita Rai was changing the world. Though it is told both men and women are equal to the outer world. When a women tries to break the stereotypical of a traditional they are stopped by the patriarchal society. Dr. Rai is accused of this Nandita Rai a renowned person herself couldn't fight against her own husband and son. She could not raise her voice with her own family member. Then, how an ordinary woman could fight against the injustice happening to them. The identity of the child is killed in the womb of the mother itself. Dr. Rai was psychologically affected by the incident made by her only son, whom she loves the most.

In the place Nandita Rai unvoiced the truth which is known to against her only son Nishant been guilt for the raping of Priyanka Kapoor. Therefore, Dr. Rai Accussed of sex-selective abortion says, I do not want a boy to be born in a house that does not respect equality? And I do not want a girl born into a household that wants to know the sex of a foetus. There are laws of the land that the court is obliged to uphold, and I respect that. The court has found me guilty of breaking a law, and I will serve the sentence because I accept I have broken the law". (HBB 284) For generations, millennia perhaps, we've passed down this legend to make source we don't forget the horror of killing seven baby boys. Yet, for the millions of girls that we have killed in the womb or as newborn babies, just because they were girls entering a world of men, not even on story. (HBB 240)

I have heard you talk in public, the wonderful things you said about how girls should be lived, how women must be respected, how much different one person can make. When you want to attack my husband-justifiably, I might add-why did not you pick a colleague of his? Or an employee? Why did you pick his wife? "Because you think I'm his property.” (HBB 247) Dr. Rai isolates herself from this humanoid world and lives in a digital world with considering that kalisthenics (a Google website) has her life. She feels that the world has taken everything from her except this website in which she shares her hope, triumph, sadness and her dream.

"Instead of aborting male foetuses, you were aborting the ones you were supposed to save, says vikram." (HBB 254) "we're doing this because we want girls and women 
to be valued, to be respected, to be remembered. We were doing this to prevent more Priyankas, to make sure girls and their stories are not dismissed like she was."(HBB 256) and female feticide achieves that? Dr. Rai thinks that this is the only way by which the value of women will be realized by the society. "We wanted justice and we choose violence because it's the only language our society seems to understand today?(HBB 256) " when you saw only one set of footprints, it was then that I carried you?"(HBB 264) this sex of the foetus was quite obviously described as anencephaly- it's a life-threatening birth defect. The foetuses is prevented from becoming girls would have happy, secure lives? Can they promise those unborn girls a life untainted by prejudice and gender bias? That they would not be harassed outside their homes and molested within, if not raped? (HBB 284).

Change is in the hands of those who wish to make a difference. Men use the power for both protection and destruction of women. In the case of Priyanka Kapoor also happen the same, when a complaint filed against Nishant for raping Priyanka Kapoor, his father because of his influence hides everything and does injustice to the girl. Dr. Rai being a woman can understand the painful situation of the girl who commits suicide. Dr. Rai wants to get justice for the death of the young innocent girl through a different way that no one can imagine it. Rai uses a different type of weapon against this patriarchal society to save the future of the girl child. And also she wants the society to regret for the injustices happened for them.

\section{CONCLUSION}

Through the novels, Hush a Bye Baby Deepanjana Pal gives a message to the reader that the acceptance difference of men and women in the society cause him or her to do crime as its consequence. The anger and frustration made Dr. Rai to choose the wrong path in her life because of her only son Nishant Most of the killer has a been a victim of this society, says the Indian philosophy, this debut novel of Pal can be considered as a awareness creating to the society.

\section{REFERENCES}

"9 Indian Female Writers Who Enriched The World of Historical Fiction.” womensweb, 29 oct. 2019. https:// www.womensweb.in/2019/10/9-indian-female-writerswho-enriched-the-world-of-historical-fiction "Childhood gender nonconformity." wikipedia, 11 Mar. 2021, https://en.wikipedia.org/wiki/Childhood_gender_ nonconformity .

Pal, Deepanjana. (2018) Hush A Bye Baby. Juggernaut Books New Delhi.

Brogaard, Berit, (2012) " The MInd of a Serial Killer." Psychology Today.7 Dec.

www.atmostfear-entertainment.com/health/psychology/ the-serial-killers-psychilogy-motivation-for-killing Ed,Gain, (1960) performer.psycho.Shamley Production. 